\title{
PLASMA CHOLINESTERASE ACTIVITY IN LIVER DISEASE: ITS VALUE AS A DIAGNOSTIC TEST OF LIVER FUNCTION COM- PARED WITH FLOCCULATION TESTS AND PLASMA PROTEIN DETERMINATIONS ${ }^{1}$
}

\author{
By ANDREW WILSON, R. J. CALVERT, AND H. GEOGHEGAN \\ (From the Department of Pharmacology, University College, London, and the Medical Unit, \\ University College Hospital Medical School, London, England)
}

(Submitted for publication July 16, 1951; accepted June 27, 1952)

The physiological significance of plasma cholinesterase is not clearly understood, but attention has recently been focussed on its relation to protein metabolism. It has been identified in high concentration in the $\alpha_{2}$ globulin of Cohn's fraction IV-6-3 (1).

The evidence which has accumulated suggests that the liver is the probable source of plasma cholinesterase ; and low values of plasma cholinesterase activity have been reported in patients with liver disease (2-11). We have been investigating acetylcholine and water metabolism in liver disease, and the present communication is an account of work undertaken to determine in which types of liver and biliary tract disease the plasma cholinesterase activity is deranged, and what diagnostic significance can be attached to these findings. Concurrent determinations of plasma proteins and flocculation tests were also made.

\section{MATERIAL AND METHODS}

The observations were carried out on 43 patients with liver and biliary tract disease. Of these, 15 patients were suffering from acute, four from sub-acute, 14 from chronic liver disease, and ten from extra-hepatic biliary obstruction. The plasma cholinesterase activity of 144 normal subjects was also studied; of these, 100 were healthy blood donors, and 44 were convalescent patients in hospital, who had no history or clinical evidence of liver disease; concurrent protein estimations were also made on the plasma of the latter patients.

Specimens of venous blood were transferred immediately after collection to heparinized tubes and centrifuged. After separation of the plasma, the red cells were washed twice with normal saline, and then laked with an amount of distilled water equal to the original volume of the

1 The expenses of this work were defrayed partially by a grant from the Medical Research Council, from whom one of us (R. J. C.) is in receipt of a whole-time grant, and by financial assistance from the Ministry of Supply, from whom one of us (H. G.) receives a wholetime grant. plasma. The cholinesterase activity of each specimen of plasma and red cells was determined manometrically in duplicate at $38^{\circ} \mathrm{C}$. by the method of Mendel, Mundell and Rudney (12), using the specific substrates, benzoylcholine chloride $(0.006 \mathrm{M})$ for estimation of plasma cholinesterase activity, and acetyl $\beta$-methylcholine chloride $(0.03 \mathrm{M})$ for true cholinesterase. Cholinesterase activity is expressed as the amount of $\mathrm{CO}_{2}$ in $\mu \mathrm{L}$ liberated in 60 minutes from $1 \mathrm{ml}$. of plasma, or laked red cell preparation.

Plasma protein estimations were made in duplicate, using the micro-Kjeldahl procedure. The globulin fraction was precipitated with 42 per cent sodium sulphite $\left(\mathrm{Na}_{2} \mathrm{SO}_{3} \cdot 7 \mathrm{H}_{2} \mathrm{O}\right)$ by the method of King (13), and determinations were made of total protein and albumin. Concurrent flocculation tests were carried out on specimens of serum from all patients with liver and biliary tract disease, using the colloidal red (Maizels [14]), cephalin cholesterol flocculation (Hanger [15]), and thymol turbidity (Maclagan [16]) tests, according to the methods previously described by Maizels (14).

In assessing the value of plasma cholinesterase activity as a diagnostic test of liver and biliary tract disease a comparison has been made with the results obtained for plasma albumin and globulin and the serum flocculation tests. For the interpretation of the flocculation tests we have adopted as an index of abnormality the conventional standards used in this hospital (14), for the colloidal red and cephalin cholesterol tests, flocculation greater than one plus $(+)$ at 24 hours, and for the thymol turbidity test a value greater than 4 units.

\section{RESULTS}

It will be convenient to begin by comparing the total results of the 33 patients with liver disease with those of the normal subjects in respect of plasma cholinesterase activity, plasma albumin and globulin estimations. Our aim here is to determine the limits of normality for these tests. The results have been plotted and give the overlapping histograms seen in Figure 1. The best discrimination will be given by the point on the scale where the two distributions (A) normal and (B) diseased intersect. A discrimination at this point 


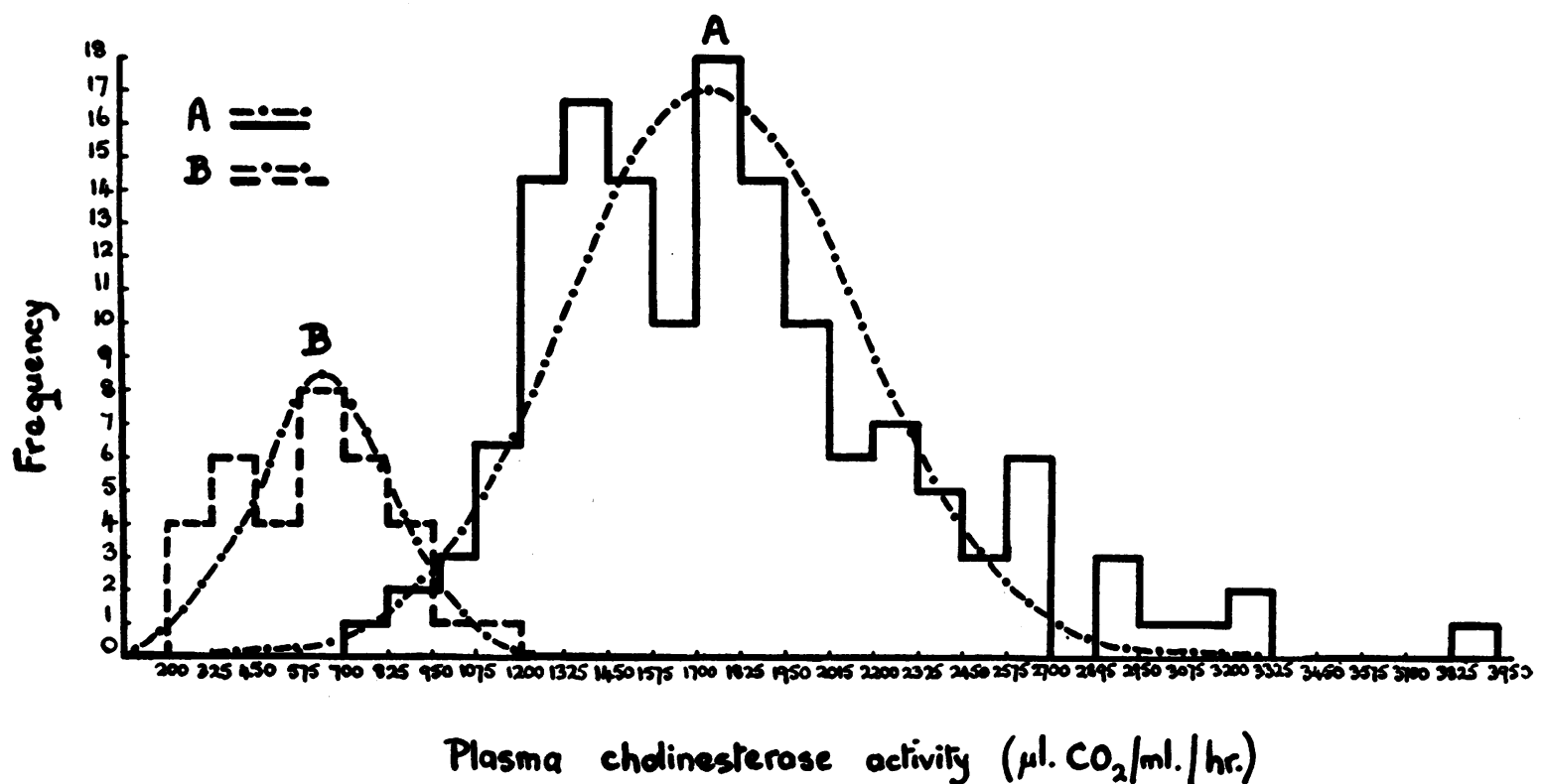

Fig. 1. Frequency Distribution of Values for Plasma Cholinesterase Activity of (A) 100 Normal Subjects and 44 Convalescent Pattents in Hospital with No Evidence of Liver Disease and (B) 33 Patients WITH LIVER Disease

will yield a minimum number of misclassifications; that is, it will minimize the number of normal subjects (A) wrongly classified as abnormal (B), and of patients with liver disease (B) wrongly classified as normal (A). For purposes of calculating this discriminative point (Burt [17]), ${ }^{2}$ it has been assumed in each case that the overlapping halves of the two samples are halves of two normal distributions. Since there was evidence that some

2 The discriminating points given in the text were calculated by the formula

$$
X=\frac{\mathrm{d} \sigma_{1}^{2}-\sigma_{1} \sigma_{2} \sqrt{\mathrm{d}^{2}+2\left(\sigma_{1}^{2}-\sigma_{2}{ }^{2}\right) \log _{e} \frac{\sigma_{1} N_{2}}{\sigma_{2} N_{1}}}}{\sigma_{1}^{2}-\sigma_{2}{ }^{2}},
$$

where $\sigma_{1}$ and $\sigma_{2}$ are the standard deviations of the two groups, $N_{1}$ and $N_{2}$, the numbers in the two groups, and $d$ the difference between the medians.

This minimizes the total number of misclassifications. If it is argued that we should aim rather at equalizing the number (or the likelihood) of misclassifications in either group, then, as Burt has suggested, we should take

$$
X=\frac{\sigma_{1} N_{1} \bar{x}_{2}+\sigma_{2} N_{2} \bar{x}_{1}}{\sigma_{1} N_{1}+\sigma_{2} N_{2}}
$$

where $\overline{\mathbf{x}}_{1}$ and $\overline{\mathbf{x}}_{2}$ denote (as usual) the means for the two groups and $d-\bar{x}_{2}-\bar{x}_{1}$. As calculation has shown, with our own data the two formulas lead to very much the same numerical values. of the distributions were slightly skewed, the measurements have been taken from the median rather than from the mean, and the standard deviations have been calculated from the adjacent or overlapping halves only.

The smoothed curve represents a hypothetical "normal distribution" having the same mean, standard deviation and number of cases as in the histogram. Since the asymmetry of the curves is not very great, the standard deviations calculated from the overlapping halves only have been used for the whole curves.

\section{1a. Plasma cholinesterase activity}

The values for normal subjects ranged from 818 to 3,265 with a mean value of 1,790 . For the 33 patients with liver disease the mean value was 612 , with a range of 238 to 1,086 . These results have been plotted as a frequency distribution curve in Figure 1. The discriminative point is 936 and values less than this have been taken as an index of abnormality. The number of misclassifications thus produced will be 3.3 per cent of the total; 6.1 per cent liver disease patients being classified as normal, and 2.6 per cent of normal subjects as suffering from liver disease. 


\section{1b. Red cell cholinesterase activity}

A quantitative analysis of the results fails to reveal any statistically significant differences between the red cell cholinesterase values of patients with liver disease and those of normal subjects.

\section{1c. Plasma proteins}

The mean value obtained for normal plasma albumin was $4.5 \mathrm{G}$. per cent (S.E. \pm 0.06 ) and for plasma globulin, 2.7 G. per cent (S.E. \pm 0.08 ). A calculation of the best discriminative point indicates that the lower limit of normality for plasma albumin may best be taken as $4.0 \mathrm{G}$. per cent and the corresponding upper limit for plasma globulin as $3.2 \mathrm{G}$. per cent. The discriminative point thus suggested for albumin values yields about 14.8 per cent misclassifications out of the total; 26.8 per cent of patients with liver disease, and 5.5 per cent of convalescent patients being wrongly classified. For globulin the borderline yields 16.7 per cent misclassifications out of the total; 29.1 per cent of liver disease patients and 7.1 per cent of convalescent patients being misclassified. It may be added that the usual statistical tests left no doubt that the discrimination was fully significant.

\section{Patients with acute liver disease}

This group of 15 patients including six (cases $1,5,8,9,10,11$ ) with homologous serum jaundice, was investigated in the icteric stage. All had typical signs and symptoms of acute virus hepatitis. Four patients were severely ill and are described as fulminating, three died within 48 hours of admission; 11 patients were moderately ill and were finally discharged from the hospital free from signs and symptoms. The diagnosis of five cases was confirmed by biopsy or autopsy. The results are summarized in Table I.

In the fulminating type the results of all tests were abnormal. There was, however, some divergence in agreement between the results for the moderately ill patients. Thus, although 82 per cent of these patients had abnormal values for plasma cholinesterase activity and positive flocculation tests, the cases in which the plasma cholinesterase activity was normal were different from the two with negative flocculation tests. The albumin and globulin levels were abnormal in only two cases. Considered as a whole, the flocculation tests and plasma cholinesterase activity are equally sensitive in indicating impairment of liver

TABLE I

Results of flocculation tests, plasma cholinesterase activity, plasma albumin and plasma globulin determinations on 15 patients with acute liver disease

\begin{tabular}{|c|c|c|c|c|c|c|c|c|}
\hline \multirow[b]{2}{*}{ Severity } & \multirow[b]{2}{*}{ Case no. } & \multicolumn{4}{|c|}{ Flocculation tests } & \multirow{2}{*}{$\begin{array}{c}\text { Plasma } \\
\text { cholinesterase } \\
\text { activity } \\
\mu L \mathrm{CO}_{2} / \mathrm{ml} . / \mathrm{hr} .\end{array}$} & \multicolumn{2}{|c|}{ Plasma proteins } \\
\hline & & $\begin{array}{l}\text { Coll. } \\
\text { red }\end{array}$ & $\begin{array}{l}\text { Ceph. } \\
\text { chol. }\end{array}$ & $\begin{array}{c}\text { Thymol } \\
\text { turb. } \\
\text { units }\end{array}$ & $\begin{array}{l}\text { Collect.* } \\
\text { interpretn. }\end{array}$ & & $\underset{G \%}{\text { Albumin }}$ & $\underset{G \%}{\text { Globulin }}$ \\
\hline Fulminating & $\begin{array}{l}1 \\
2 \\
3 \\
4\end{array}$ & $\begin{array}{c}++++ \\
+++ \\
+++ \\
++++\end{array}$ & $\begin{array}{c}t+++ \\
+++ \\
++t+ \\
+++\end{array}$ & $\begin{array}{r}12 \\
12 \\
10 \\
9\end{array}$ & $\begin{array}{l}\text { positive } \\
\text { positive } \\
\text { positive } \\
\text { positive }\end{array}$ & $\begin{array}{l}414 \\
523 \\
578 \\
696\end{array}$ & $\begin{array}{l}2.6 \\
3.6 \\
3.5 \\
2.5\end{array}$ & $\begin{array}{l}3.6 \\
4.4 \\
3.8 \\
4.2\end{array}$ \\
\hline Nonfulmin. & $\begin{array}{r}5 \\
6 \\
7 \\
8 \\
9 \\
10 \\
11 \\
12 \\
13 \\
14 \\
15\end{array}$ & $\begin{array}{r}+++ \\
++ \\
++++ \\
++++ \\
+++ \\
+++ \\
0 \\
+++ \\
++ \\
++ \\
0\end{array}$ & $\begin{array}{r}t++ \\
++ \\
++++ \\
+++ \\
+++ \\
++++ \\
+++ \\
++++ \\
++ \\
0 \\
0\end{array}$ & $\begin{array}{r}18 \\
5 \\
7 \\
8 \\
12 \\
8 \\
9 \\
22 \\
5 \\
4 \\
3\end{array}$ & $\begin{array}{l}\text { positive } \\
\text { positive } \\
\text { positive } \\
\text { positive } \\
\text { positive } \\
\text { positive } \\
\text { positive } \\
\text { positive } \\
\text { positive } \\
\text { negative } \\
\text { negative }\end{array}$ & $\begin{array}{r}238 \\
635 \\
719 \\
722 \\
731 \\
856 \\
928 \\
968 \\
1,086 \\
834 \\
792\end{array}$ & $\begin{array}{l}2.5 \\
4.1 \\
4.1 \\
5.2 \\
4.3 \\
3.5 \\
4.4 \\
4.3 \\
4.3 \\
4.5 \\
4.8\end{array}$ & $\begin{array}{l}3.2 \\
2.9 \\
3.5 \\
2.9 \\
3.4 \\
3.1 \\
2.1 \\
2.9 \\
2.7 \\
3.1 \\
2.0\end{array}$ \\
\hline $\begin{array}{l}\text { Total no. with } \\
\text { abnormal values }\end{array}$ & & & & & 13 & 13 & 6 & 6 \\
\hline
\end{tabular}

* The collective interpretation of the flocculation tests was assessed as positive where two or more tests were abnormal. 
TABLE II

Results of flocculation tests, plasma cholinesterase activity, albumin and globulin determinations at the time of discharge from hospital in seven patients recovering (late) from acute liver disease, compared with the results obtained during acute illness (early)

\begin{tabular}{|c|c|c|c|c|c|c|c|c|c|}
\hline \multirow{2}{*}{ Case no. } & \multirow{2}{*}{ Phase } & \multicolumn{4}{|c|}{ Flocculation tests } & \multirow{2}{*}{$\begin{array}{c}\text { Plasma } \\
\text { cholinesterase } \\
\text { activity } \\
\mu L C O_{2} / m l . / h r\end{array}$} & \multicolumn{2}{|c|}{ Plasma proteins } & \multirow{2}{*}{$\begin{array}{l}\text { Interval } \\
\text { between } \\
\text { early an } \\
\text { late test } \\
\text { weeks }\end{array}$} \\
\hline & & Coll. red & Ceph. chol. & $\begin{array}{c}\text { Thymol } \\
\text { turb. units }\end{array}$ & $\begin{array}{l}\text { Collective* } \\
\text { interpretn. }\end{array}$ & & $\underset{G \%}{\text { Albumin }}$ & $\begin{array}{l}\text { Globulin } \\
G \%\end{array}$ & \\
\hline 1 & $\begin{array}{l}\text { Late } \\
\text { Early }\end{array}$ & $\begin{array}{c}+++ \\
++t\end{array}$ & $\begin{array}{r}+++ \\
++t+\end{array}$ & $\begin{array}{l}12 \\
12\end{array}$ & $\begin{array}{l}\text { positive } \\
\text { positive }\end{array}$ & $\begin{array}{r}2,708 \\
414\end{array}$ & $\begin{array}{l}3.9 \\
2.6\end{array}$ & $\begin{array}{l}3.2 \\
3.6\end{array}$ & 6 \\
\hline 5 & $\begin{array}{l}\text { Late } \\
\text { Early }\end{array}$ & $\begin{array}{r}+t \\
++t\end{array}$ & $\begin{array}{l}+t \\
++t\end{array}$ & $\begin{array}{r}9 \\
18\end{array}$ & $\begin{array}{l}\text { positive } \\
\text { positive }\end{array}$ & $\begin{array}{r}1,383 \\
238\end{array}$ & $\begin{array}{l}4.0 \\
2.5\end{array}$ & $\begin{array}{l}3.2 \\
3.2\end{array}$ & 6 \\
\hline 6 & $\begin{array}{l}\text { Late } \\
\text { Early }\end{array}$ & $\begin{array}{l}++ \\
++\end{array}$ & $\begin{array}{l}++ \\
++\end{array}$ & $\begin{array}{l}5 \\
5\end{array}$ & $\begin{array}{l}\text { positive } \\
\text { positive }\end{array}$ & $\begin{array}{r}1,381 \\
635\end{array}$ & $\begin{array}{l}3.8 \\
4.1\end{array}$ & $\begin{array}{l}2.8 \\
2.9\end{array}$ & 2 \\
\hline 7 & $\begin{array}{l}\text { Late } \\
\text { Early }\end{array}$ & $+\begin{array}{r}0 \\
+++\end{array}$ & $\begin{array}{r}0 \\
++++\end{array}$ & 2 & $\begin{array}{l}\text { negative } \\
\text { positive }\end{array}$ & $\begin{array}{r}1,490 \\
719\end{array}$ & $\begin{array}{l}4.2 \\
4.1\end{array}$ & $\begin{array}{l}3.2 \\
3.5\end{array}$ & 9 \\
\hline 8 & $\begin{array}{l}\text { Late } \\
\text { Early }\end{array}$ & $+++t^{0}$ & $\begin{array}{r}0 \\
+++\end{array}$ & $\begin{array}{l}4 \\
8\end{array}$ & $\begin{array}{l}\text { negative } \\
\text { positive }\end{array}$ & $\begin{array}{l}917 \\
722\end{array}$ & $\overline{5.2}$ & $\overline{2.9}$ & 4 \\
\hline 12 & $\begin{array}{l}\text { Late } \\
\text { Early }\end{array}$ & $\begin{array}{l}++++ \\
++++\end{array}$ & $\begin{array}{r}+++ \\
+++\end{array}$ & $\begin{array}{l}12 \\
22\end{array}$ & $\begin{array}{l}\text { positive } \\
\text { positive }\end{array}$ & $\begin{array}{r}1,508 \\
968\end{array}$ & $\begin{array}{l}4.5 \\
4.3\end{array}$ & $\begin{array}{l}3.0 \\
2.9\end{array}$ & 1 \\
\hline 13 & $\begin{array}{l}\text { Late } \\
\text { Early }\end{array}$ & $+t$ & $\begin{array}{r}0 \\
++\end{array}$ & 2 & $\begin{array}{l}\text { negative } \\
\text { positive }\end{array}$ & $\begin{array}{l}1,532 \\
1,086\end{array}$ & $\begin{array}{l}4.3 \\
4.3\end{array}$ & $\begin{array}{l}3.3 \\
2.7\end{array}$ & 5 \\
\hline
\end{tabular}

* The collective interpretation of the flocculation tests was assessed as positive where two or more tests were abnormal.

function in patients with acute liver disease ( 87 per cent abnormal).

These tests were repeated on seven patients, at intervals until they were free from signs and symptoms of liver disease. A comparison is shown in Table II of the results obtained when the patients were acutely ill and when they had recovered sufficiently to be discharged from hospital. Whereas plasma cholinesterase values had returned to within normal limits in all but one of the patients, positive flocculation tests were still observed in

TABLE III

Results of flocculation tests, plasma cholinesterase activity, albumin and globulin determinations on four patients with sub-acute hepatitis

\begin{tabular}{|c|c|c|c|c|c|c|c|}
\hline \multirow{2}{*}{$\begin{array}{c}\text { Case } \\
\text { no. }\end{array}$} & \multicolumn{4}{|c|}{ Flocculation tests } & \multirow{2}{*}{$\begin{array}{l}\text { Plasma } \\
\text { cholin- } \\
\text { esterase } \\
\text { activity } \\
\mu L C O_{2} / \\
m l . / h r .\end{array}$} & \multicolumn{2}{|c|}{$\begin{array}{c}\text { Plasma } \\
\text { proteins }\end{array}$} \\
\hline & $\begin{array}{l}\text { Coll. } \\
\text { red }\end{array}$ & $\begin{array}{l}\text { Ceph. } \\
\text { chol. }\end{array}$ & $\begin{array}{c}\text { Thymol } \\
\text { turb. } \\
\text { units }\end{array}$ & $\begin{array}{l}\text { Collec- } \\
\text { tive* } \\
\text { inter- } \\
\text { pretn. }\end{array}$ & & $\underset{\boldsymbol{G} \%}{\mathrm{Al}-}$ & 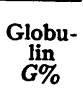 \\
\hline $\begin{array}{l}16 \\
17 \\
18 \\
19\end{array}$ & & & $\begin{array}{r}7 \\
7 \\
9 \\
20\end{array}$ & $\begin{array}{l}\text { positive } \\
\text { positive } \\
\text { positive } \\
\text { positive }\end{array}$ & $\begin{array}{l}280 \\
469 \\
280 \\
447\end{array}$ & $\begin{array}{l}1.8 \\
3.5 \\
1.7 \\
3.9\end{array}$ & $\begin{array}{l}3.6 \\
3.5 \\
4.4 \\
4.0\end{array}$ \\
\hline
\end{tabular}

* The collective interpretation of the flocculation tests was assessed as positive where two or more tests were abnormal. four patients. Although the plasma globulin levels were normal in the acute phase as well as at the time of discharge, in some cases abnormal values were observed during the course of illness. In following up patients whose plasma cholinesterase and albumin levels were originally less than normal, it was not possible to conclude definitely whether plasma cholinesterase activity or albumin had first returned to normal.

\section{Patients with sub-acute hepatitis}

Four patients whose signs and symptoms had persisted for between two and four months are considered as a separate group; this is in general agreement with the classification of Kelsall, Stewart and Witts (18). All patients were jaundiced and had enlargement of the liver. Vascular spiders, and signs and symptoms involving the central nervous system, were noted in Cases 16 and 17 , each of whom developed a terminal coma and died within a week of the observations. A diagnosis of sub-acute hepatic necrosis was confirmed at autopsy. One patient, Case 18, had one month previously recovered from hepatic coma, and Case 19 was admitted in relapse after treatment lasting two months in another hospital. 
The severity of illness bore a striking resemblance to that of the patients with severe acute liver disease, and the results of the tests, shown in Table III, are very similar to those shown in Table I. Plasma cholinesterase levels were all extremely low ; strongly positive flocculation tests, low plasma albumin and high globulin levels were also observed. Serial estimations of plasma cholinesterase activity in the two patients who survived (Cases 18 and 19), reflected the gradual process of recovery in advance of the changes shown by the other tests.

\section{Patients with chronic liver disease}

The 14 patients included in this group consisted of five cases of chronic hepatitis, seven of portal cirrhosis, one with primary biliary cirrhosis, and one with congestive cirrhosis of the liver. The patients with chronic hepatitis had a history of an acute attack with jaundice, and were observed at a period of about one year after the acute attack; the clinical evidence of liver disease was as marked as in the patients with portal cirrhosis. Jaundice was present in about a quarter of the patients. Portal hypertension was a feature of the group with portal cirrhosis, but was also frequently observed in patients with chronic hepati- tis. There was clinical evidence of water retention in approximately two-thirds of the patients in each group. The clinical diagnosis was confirmed by biopsy or autopsy in ten patients.

Low plasma cholinesterase values were observed in all the patients ; in contrast, the flocculation tests were negative in more than half the cases of portal cirrhosis (Table IV). In general, low plasma albumin levels were observed, but the plasma globulin was raised in only about half of the patients with portal cirrhosis. With regard to the flocculation tests and plasma globulin values, there appears to be a clear distinction between patients with chronic hepatitis and those with portal cirrhosis, but the reasons for this are obscure. As a diagnostic measure, however, it is obvious that the estimation of plasma cholinesterase activity provides a more sensitive index of impairment of liver function than is obtained with other tests.

\section{Patients with extra-hepatic biliary obstruction}

Ten patients with extra-hepatic biliary obstruction were studied, and in all but one (Case 43), the diagnosis was confirmed at operation or autopsy. One patient (Case 34) was observed during his fifth attack of biliary colic and although previous attacks had usually been associated with

TABLE IV

Results of flocculation tests, plasma cholinesterase activity, plasma albumin and globulin determinations on 14 patients with chronic liver disease

\begin{tabular}{|c|c|c|c|c|c|c|c|c|}
\hline \multirow[b]{2}{*}{ Diagnosis } & \multirow[b]{2}{*}{ Case no. } & \multicolumn{4}{|c|}{ Flocculation tests } & \multirow{2}{*}{$\begin{array}{c}\text { Plasma } \\
\text { cholinesterase } \\
\text { activity } \\
\mu L C \mathrm{C}_{2} / \mathrm{ml} . / \mathrm{hr} .\end{array}$} & \multicolumn{2}{|c|}{ Plasma proteins } \\
\hline & & Coll. red & Ceph. chol. & $\begin{array}{l}\text { Thymol } \\
\text { turb. } \\
\text { units }\end{array}$ & $\begin{array}{l}\text { Collective* } \\
\text { interpretn. }\end{array}$ & & $\underset{G \%}{\text { Albumin }}$ & $\begin{array}{l}\text { Globulin } \\
\text { G\% }\end{array}$ \\
\hline Chronic hepatitis & $\begin{array}{l}20 \\
21 \\
22 \\
23 \\
24\end{array}$ & & $\begin{array}{r}t++ \\
+ \\
+ \\
++t \\
+++t\end{array}$ & $\begin{array}{r}13 \\
8 \\
12 \\
11 \\
10\end{array}$ & $\begin{array}{l}\text { positive } \\
\text { positive } \\
\text { positive } \\
\text { positive } \\
\text { positive }\end{array}$ & $\begin{array}{l}290 \\
354 \\
418 \\
425 \\
466\end{array}$ & $\begin{array}{l}1.9 \\
2.7 \\
2.4 \\
2.9 \\
4.0\end{array}$ & $\begin{array}{l}3.8 \\
3.5 \\
4.3 \\
4.4 \\
4.2\end{array}$ \\
\hline Portal cirrhosis & $\begin{array}{l}25 \\
26 \\
27 \\
28 \\
29 \\
30 \\
31\end{array}$ & $\begin{array}{r}+ \\
0 \\
0 \\
0 \\
++\end{array}$ & $\begin{array}{r}++ \\
+++ \\
+++ \\
0 \\
0 \\
+ \\
0\end{array}$ & $\begin{array}{r}17 \\
12 \\
15 \\
3 \\
3 \\
3 \\
3\end{array}$ & $\begin{array}{l}\text { positive } \\
\text { positive } \\
\text { positive } \\
\text { negative } \\
\text { negative } \\
\text { negative } \\
\text { negative }\end{array}$ & $\begin{array}{l}671 \\
676 \\
790 \\
559 \\
578 \\
635 \\
891\end{array}$ & $\begin{array}{l}4.0 \\
3.5 \\
2.8 \\
3.1 \\
3.9 \\
3.2 \\
3.0\end{array}$ & $\begin{array}{l}3.9 \\
4.2 \\
4.2 \\
2.3 \\
3.1 \\
3.0 \\
4.5\end{array}$ \\
\hline $\begin{array}{l}\text { Primary biliary } \\
\text { cirrhosis }\end{array}$ & 32 & ++ & ++ & 3 & positive & 735 & 3.4 & 3.6 \\
\hline Congest. cirrhosis & 33 & + & 0 & 3 & negative & 638 & 3.7 & 2.9 \\
\hline
\end{tabular}
normal.

* The collective interpretation of the flocculation tests was assessed as positive where two or more tests were ab- 
TABLE V

Results of flocculation tests, plasma cholinesterase activity, plasma albumin and globulin determinations on ten patients with extra-hepatic biliary obstruction

\begin{tabular}{|c|c|c|c|c|c|c|c|c|c|}
\hline \multirow[b]{2}{*}{ Diagnosis } & \multirow[b]{2}{*}{$\begin{array}{c}\text { Case } \\
\text { no. }\end{array}$} & \multirow{2}{*}{$\begin{array}{c}\text { Duration } \\
\text { of } \\
\text { jaundice } \\
\text { weeks }\end{array}$} & \multicolumn{4}{|c|}{ Flocculation tests } & \multirow{2}{*}{$\begin{array}{l}\text { Plasma } \\
\text { cholinesterase } \\
\text { activity } \\
\mu L C \mathrm{C}_{2} / \text { ml./hr. }\end{array}$} & \multicolumn{2}{|c|}{ Plasma proteins } \\
\hline & & & $\begin{array}{l}\text { Coll. } \\
\text { red }\end{array}$ & $\begin{array}{l}\text { Ceph. } \\
\text { chol. }\end{array}$ & $\begin{array}{l}\text { Thymol } \\
\text { turb. } \\
\text { units }\end{array}$ & $\begin{array}{l}\text { Collective* } \\
\text { interpretn. }\end{array}$ & & $\underset{G \%}{\text { Albumin }}$ & Globulin \\
\hline $\begin{array}{l}\text { Choledocholithiasis S-A cholangitis } \\
\text { Choledocholithiasis-acute cholangio- } \\
\text { hepatitis }\end{array}$ & $\begin{array}{l}34 \\
35\end{array}$ & $\begin{array}{l}0 \\
1\end{array}$ & $\begin{array}{l}0 \\
+\end{array}$ & $\begin{array}{l}\mathbf{0} \\
\mathbf{0}\end{array}$ & $\begin{array}{l}2 \\
2\end{array}$ & $\begin{array}{l}\text { negative } \\
\text { negative }\end{array}$ & $\begin{array}{r}1,700 \\
873\end{array}$ & $\begin{array}{l}4.5 \\
4.2\end{array}$ & $\begin{array}{l}2.9 \\
1.9\end{array}$ \\
\hline $\begin{array}{l}\text { Recurrent biliary obstruction. Polyp } \\
\text { in duodenum near ampulla of Vater }\end{array}$ & 36 & 1 & $\mathbf{0}$ & $\mathbf{0}$ & 1 & negative & 1,956 & 4.5 & 2.6 \\
\hline $\begin{array}{l}\text { Carcinoma of head of pancreas } \\
\text { Choledocholithiasis adenocarcinoma of } \\
\text { gallbladder }\end{array}$ & $\begin{array}{l}37 \\
38\end{array}$ & $\begin{array}{l}1 \\
5\end{array}$ & $\begin{array}{l}\mathbf{0} \\
\mathbf{0}\end{array}$ & $\begin{array}{l}\mathbf{0} \\
\mathbf{0}\end{array}$ & $\begin{array}{l}1 \\
1\end{array}$ & $\begin{array}{l}\text { negative } \\
\text { negative }\end{array}$ & $\begin{array}{l}2,293 \\
1,209\end{array}$ & $\begin{array}{l}3.9 \\
4.4\end{array}$ & $\begin{array}{l}3.1 \\
2.7\end{array}$ \\
\hline $\begin{array}{l}\text { Carcinoma of ampulla of Vater } \\
\text { Carcinoma of ampulla of Vater } \\
\text { Carcinoma of common bile duct; ex- } \\
\text { tensive secondary hepatic metas- } \\
\text { tases }\end{array}$ & $\begin{array}{l}39 \\
40 \\
41\end{array}$ & $\begin{array}{r}8 \\
9 \\
22\end{array}$ & $\begin{array}{l}\mathbf{0} \\
\mathbf{0} \\
\mathbf{0}\end{array}$ & $\begin{array}{l}\mathbf{0} \\
\mathbf{0} \\
\mathbf{0}\end{array}$ & $\begin{array}{l}2 \\
5 \\
1\end{array}$ & $\begin{array}{l}\text { negative } \\
\text { negative } \\
\text { negative }\end{array}$ & $\begin{array}{r}1,461 \\
828 \\
657\end{array}$ & $\begin{array}{l}3.2 \\
3.6 \\
3.3\end{array}$ & $\begin{array}{l}3.7 \\
3.4 \\
3.9\end{array}$ \\
\hline $\begin{array}{l}\text { Choledocholithiasis } \\
\text { Recurrent cholangio-hepatitis }\end{array}$ & $\begin{array}{l}42 \\
43\end{array}$ & $\begin{array}{l}12 \\
32\end{array}$ & $\begin{array}{l}\mathbf{0} \\
\mathbf{0}\end{array}$ & $\begin{array}{l}\mathbf{0} \\
\mathbf{0}\end{array}$ & $\begin{array}{l}2 \\
4\end{array}$ & $\begin{array}{l}\text { negative } \\
\text { negative }\end{array}$ & $\begin{array}{l}1,675 \\
1,086\end{array}$ & $\begin{array}{l}3.8 \\
4.3\end{array}$ & $\begin{array}{l}3.7 \\
4.4\end{array}$ \\
\hline
\end{tabular}
normal.

* The collective interpretation of the flocculation tests was assessed as positive where two or more tests were ab-

jaundice, on the present occasion this was not observed until the day following the tests; at operation a stone was demonstrated in the cystic duct, occluding the common bile duct.

The results of the flocculation tests, plasma cholinesterase, albumin and globulin estimations are shown in Table V. The cases are arranged consecutively in order of the duration of jaundice which is indicated in column 2 ; for convenience of subsequent discussion the table is subdivided into early and late cases. The flocculation tests in all cases were consistently negative and in this respect are in marked contrast to all the other tests, in distinguishing jaundice due to extrahepatic biliary obstruction from that due to liver disease. The plasma cholinesterase values were normal in seven patients. Of the three patients with low values one (Case 36) had an acute attack of cholangiohepatitis; the other two (Cases 40 and 41) had a history of prolonged obstruction, and had subsequent evidence of malignant disease. Plasma albumin levels were normal in all but one of the early group and abnormal in all but one of the late group; essentially similar findings were obtained for plasma globulin levels.

\section{DISCUSSION}

It has been suggested that the low plasma cholinesterase activity observed in patients with liver disease may be due to an inhibitor substance (3), but there is no satisfactory evidence to support this hypothesis (4). In a series of experiments involving incubation of normal plasma with that from patients with liver disease, we have been unable to demonstrate an inhibitory effect; using techniques previously described (19) we have not observed any difference from normal in the plasma cholinesterase of patients with liver disease with respect to optimum substrate concentration or the in vitro inhibition produced by the anti-cholinesterase compounds di-isopropylfluorophosphonate and neostigmine.

We have explored the variations in plasma cholinesterase activity of patients with acute, subacute and chronic liver disease, and have attempted to define more precisely the value of this test in comparison with the flocculation tests and plasma albumin and globulin levels. The collective information obtained from all these patients has confirmed the reliability of a low value for plasma cholinesterase activity as an index of impaired liver function. In severe acute liver disease this test does not contribute more information than is obtained by the other tests, but in patients who are less severely affected, the test is as sensitive as the flocculation tests, and much more reliable than estimations of plasma albumin and globulin. Grob and his colleagues (8) have drawn attention 
to the apparent lack of precision of this test in acute as compared with chronic liver disease. Vorhaus, Scudamore, and Kark (20) on the other hand have commented on the reliability of plasma cholinesterase estimations as an index of biochemical relapse in following up patients with acute hepatitis, in contrast to other liver function tests. We have also shown that, while normal values for plasma cholinesterase activity may be obtained in conjunction with positive flocculation tests, this apparent anomaly is indeed an indication of the immediate prognostic value of the test, since it reflects in advance of the flocculation tests the phase of recovery. A question of considerable interest is whether at the beginning of an acute attack of liver disease, depression of plasma cholinesterase activity occurs before, concurrently with, or after the development of positive flocculation tests.

Our observations on patients with sub-acute liver disease are restricted to four cases in whom all tests were positive; plasma cholinesterase estimations merely confirm the severity of this type of liver disease.

We have shown, as other workers have observed (21-24), that the flocculation tests are often negative in patients with chronic liver disease. We have found that this is evident particularly in those cases with portal cirrhosis, three of which had negative flocculation tests during intermittent observations throughout a period of 12 months; in contrast, low values for plasma cholinesterase activity were observed in all patients. Kunkel and Ward (9) have already drawn attention to the close relation between the low plasma albumin and low plasma cholinesterase values in chronic liver disease, and we have confirmed this by serial estimations carried out on several of our patients over periods of 12 months or more. We have failed to observe any such marked relation, however, in acute liver disease, and we consider that the conclusions of Levine and Hoyt (25) do not merit the assumption that if the serum albumin level is low, the serum cholinesterase level must also be low. Our results taken in conjunction with those of Kunkel and Ward (9) and Alcalde (11) justify the conclusion that chronic liver disease is almost invariably associated with low plasma cholinesterase activity.
The original observation by McArdle (4) that a high proportion of patients with extra-hepatic biliary obstruction have initial normal serum cholinesterase values, has been confirmed by most workers; in this respect our results are also in agreement, for, of ten patients, seven had normal plasma cholinesterase levels. There are several factors which limit the value of this test in distinguishing between jaundice due to hepatic and extra-hepatic biliary causes. One is the duration of jaundice, which, if prolonged beyond about two months, may result in low values; this was commented on by Grob and his colleagues (8) who observed low values in four patients with prolonged obstructive jaundice. Malignant disease may also produce a depression of plasma cholinesterase activity; Alcalde (11) has shown that whereas 26 patients with benign obstructive jaundice had mainly normal values, all of the 24 patients with malignant obstruction had low values. How far these low values in malignant obstruction are due directly to impairment of liver function is not clear; only two of our patients in the obstructive group had low values, yet five cases had evidence of malignant disease at operation or subsequent autopsy. Intercurrent infection of the biliary tract may also produce a transient lowering of plasma cholinesterase activity; this we have observed on several occasions during serial estimations in patients with cholangiohepatitis (Himsworth [26]).

There appears to be little relation between plasma globulin levels and the flocculation tests in extra-hepatic biliary obstruction, for in contrast to the uniformly negative flocculation tests, we have observed consistently raised plasma globulin levels when the obstruction is prolonged.

As an aid in the differential diagnosis of jaundice, estimations of plasma cholinesterase activity are less precise than the flocculation tests in confirming the extra-hepatic biliary group, but are particularly valuable in assessing concurrent impairment of liver function. When used in conjunction with the flocculation tests, they afford an immediate prognostic index of recovery in acute and subacute liver disease. The estimation of plasma cholinesterase activity is probably the most direct and sensitive method of assessing the ability of the liver to synthesize protein, and the test re- 
flects the severity of the clinical condition of patients with liver disease. The chief criticism of this test lies in the specialized technique required, but in laboratories not equipped for this purpose, the simplified method described by Michel (27), which depends on measuring changes in $\mathrm{pH}$, offers, as Vorhaus, Scudamore and Kark (10) have shown, an alternative and reliable technique.

\section{SUMMARY AND CONCLUSIONS}

1. The plasma cholinesterase activity of 100 normal subjects, 44 convalescent hospital patients with no history or clinical evidence of liver disease, and of 33 patients with liver disease has been studied. It has been shown that, compared with normal subjects and the convalescent patients, there is a significant difference in the plasma cholinesterase activity of patients with liver disease.

Values for plasma cholinesterase activity lower than $936\left(\mu \mathrm{LCO}_{2} / \mathrm{ml}\right.$./hr. $)$ are regarded as abnormal.

2. The results of plasma cholinesterase determinations have been compared with those of the flocculation tests and of plasma albumin and globulin estimations in 15 patients with acute, 4 patients with sub-acute, and 14 patients with chronic liver disease and in 10 patients with extra-hepatic biliary obstruction. It has been shown that in patients with severe acute and sub-acute liver disease, low plasma cholinesterase values provide confirmatory evidence of considerable impairment of liver function. In patients recovering from acute and sub-acute liver disease, estimations of plasma cholinesterase activity afford an immediate useful prognostic indication of recovery of liver function, since the plasma cholinesterase level returns to within normal limits in advance of the flocculation tests.

It has been observed that in patients with chronic liver disease, where the flocculation tests are sometimes normal, plasma cholinesterase and albumin levels are usually lower than normal. This evidence, however, does not appear to discriminate between cirrhosis and malignant disease of the liver.

3. Normal values for plasma cholinesterase activity are usually observed in patients with extrahepatic biliary obstruction of short duration; low values occur, however, during attacks of cholangio- hepatitis and in patients with malignant disease and prolonged obstruction. In the differential diagnosis of jaundice the results of this test are less. precise than those of the flocculation tests in defining an extra-hepatic cause for the jaundice, but when taken in conjunction with the flocculation tests provide reliable information regarding impairment of liver function.

\section{ACKNOWLEDGMENTS}

It is a pleasure to acknowledge the co-operation we have received from the Director of the Medical Unit (Professor H. P. Himsworth, and later Professor M. L. Rosenheim) and the physicians of University College Hospital in studying patients under their care. We are indebted to Sir Cyril Burt and Dr. Charlotte Banks for their valuable advice and help in preparing the statistical analysis of our results. Dr. J. O. Irwin has also been good enough to read the final draft of our manuscript and to send us his comments on the statistical treatment of our results. The flocculation tests were carried out by Dr. F. V. Flynn of the Department of Clinical Pathology; to him and to Professor M. Maizels, we record our thanks for their co-operation. We are also indebted to Mrs. Nancy Boura and Miss Joyce Cockburn for technical assistance.

\section{REFERENCES}

1. Goldstein, A., and Doherty, M. E., Properties and behaviour of purified human plasma cholinesterase. I. Stability and thermal denaturation. Arch. Biochem. \& Biophys., 1951, 33, 22.

2. Antopol, W., Tuchman, L., and Schifrin, A., Cholinesterase activity of human sera, with special reference to hyperthyroidism. Proc. Soc. Exper. Biol. \& Med., 1937, 36, 46.

3. Antopol, W., Schifrin, A., and Tuchman, L., Decreased cholinesterase activity of serum in jaundice and in biliary disease. Proc. Soc. Exper. Biol. \& Med. 1938, 38, 363.

4. McArdle, B., The serum cholinesterase in jaundice and diseases of the liver. Quart. J. Med., 1940, 9 . (new series), 107.

5. Butt, H. R., Comfort, M. W., Dry, T. J., and Osterberg, A. E., Values for acetylcholine esterase in the blood serum of normal persons and patients with various diseases. J. Lab. \& Clin. Med., 1942, 27, 649.

6. Vincent, D., and de Prat, J., Recherches préliminaires sur la cholinestérase du sérum dans les syndromes. d'insuffisance hépatique. Compt. rend. Soc. biol., 1942, 136, 821.

7. Faber, M., Serum cholinesterase in disease. Acta. med. scandinav., 1943, 114, 59.

8. Grob, D., Lilienthal, J. L., Jr., Harvey, A. M., and Jones, B. F., The administration of di-isopropyl 
fluorophosphonate (DFP) to man. I. Effect on plasma and erythrocyte cholinesterase; general systemic effects; use in study of hepatic function and erythropoiesis; and some properties of plasma cholinesterase. Bull. Johns Hopkins Hosp., 1947, 81, 217.

9. Kunkel, H. G., and Ward, S. M., Plasma esterase activity in patients with liver disease and the nephrotic syndrome. J. Exper. Med., 1947, 86, 325.

10. Vorhaus, L. J., II., Scudamore, H. H., and Kark, R. M., Measurement of serum cholinesterase activity in the study of diseases of the liver and biliary system. Gastroenterology, 1950, 15, 304.

11. Alcalde, J. M. O., Serum cholinesterase determinations in the differential diagnosis of jaundice. J. Lab. \& Clin. Med., 1950, 36, 391.

12. Mendel, B., Mundell, D. B., and Rudney, H., Studies in cholinesterase. 3. Specific tests for true cholinesterase and pseudo-cholinesterase. Biochem. J., 1943, 37, 473.

13. King, E. J., Micro-Analysis in Medical Biochemistry. Churchill, Ltd., London, 1946, p. 37.

14. Maizels, M., Empirical tests of liver function. Lancet, 1946, 2, 451.

15. Hanger, F. M., The flocculation of cephalin-cholesterol emulsions by pathological sera. Tr. A. Am. Physicians, 1938, 53, 148.

16. Maclagan, N. F., Thymol turbidity test: a new indicator of liver dysfunction. Nature, 1944, 154, 670.

17. Burt, C. L., Mental and Scholastic Tests. King \& Sons, London, 1921, p. 104.

18. Kelsall, A. R., Stewart, A., and Witts, L. J., Subacute and chronic hepatitis. Lancet, 1947, 2, 195.
19. Wilson, A., Maw, G. A., and Geoghegan, H., Cholinesterase activity of blood and muscle in myasthenia gravis. Quart. J. Med., 1951, 20 (new series), 13.

20. Vorhaus, L. J., II, Scudamore, H. H., and Kark, R. M., Measurement of serum cholinesterase activity: a useful test in the management of acute hepatitis. Am. J. M., Sc., 1951, 221, 140.

21. Neefe, J. R., Bahnson, E. R., and Reinhold, J. G., Studies of responses of certain hepatic tests in diseases of the liver and biliary tract. I. Serum cephalin cholesterol flocculation, thymol turbidity, thymol flocculation and colloidal gold response. Gastroenterology, 1947, 9, 656.

22. Mann, F. D., Snell, A. M., and Butt, H. R., The thymol turbidity test and impaired liver function. Gastroenterology, 1947, 9, 651.

23. Whitman, J. F., Rossmiller, H. R., and Lewis, L. A., Protein alteration in portal cirrhosis as determined by electrophoresis. J. Lab. \& Clin. Med., 1950, 35, 167.

24. Popper, H., and Schaffner, F., Hepatic tests. Advances in Internal Medicine. Year Book Publishers, Chicago, 1950, 4, 357.

25. Levine, M. G., and Hoyt, R. E., The relationship between human serum cholinesterase and serum albumin. Science, 1950, 111, 286.

26. Himsworth, H. P., Lectures on the liver and its diseases. Blackwell Scientific Publications, Oxford, 1947, p. 169.

27. Michel, H. O., An electrometric method for the determination of red blood cell and plasma cholinesterase activity. J. Lab. \& Clin. Med., 1949, 34, 1564. 